\title{
Water Security
}




\section{Water Security The Water-Food-Energy-Climate Nexus}

"Water sits at the nexus of so many global issues... including health, hunger and economic growth. And sadly, water scarcity takes its greatest toll on society's least fortunate. I am absolutely convinced that the only way to measurably and sustainably improve this dire situation is through broad-scale collaborative efforts between government, industry, academia and other stakeholders around the world."

-Indra Nooyi,

Chairman and CEO of PepsiCo, Inc., Member of International Business Council, World Economic Forum

"In 1911, John Muir observed how, 'When we try to pick out anything by itself in nature, we find it hitched to everything else in the Universe.' A century later, a gathering of the World Economic Forum discovered the same phenomenon. Four hundred top decision-makers listed the myriad looming threats to global stability, including famine, terrorism, inequality, disease, poverty, and climate change. Yet when we tried to address each diverse force, we found them all attached to one universal security risk: fresh water."

-Margaret Catley-Carlson, Patron, Global Water Partnership, 2008-2010 Chair of World Economic

Forum Global Agenda Council on Water Security
"To make a difference on the water challenges we all face, governments, civil society and businesses must work together as never before. For business leaders in particular, we need to speak up, stand up and scale up our efforts on water sustainability." -Muhtar Kent, Chairman and CEO, The Coca-Cola Company, Member of International Business Council, World Economic Forum
"Over the last few years, the scale and speed of response from a leading group of large companies to the water challenge has been impressive. As this book illustrates, their engagement in partnerships with others to better understand how water works across the economy and how to manage water more efficiently as a result, can offer much potential."

-Professor Tony Allan, Kings College London, 2008 Recipient of the Stockholm Water Prize, Member of the World Economic Forum Global Agenda Council on Water Security 
This publication was prepared by the World Economic Forum Water Initiative to support the Industry Partnership Programme.

Dominic Waughray, Senior Director and Head of Environmental Initiatives at the World Economic Forum, led the development, collation, and editing of this publication, supported by James G. Workman.

Industry Partners are select member companies of the

World Economic Forum that are actively involved in the Forum's mission at the industry level.

Partnerships bring visibility and insight to strategic decision-making on the most important industry- and cross-industry-related issues and the opportunity to engage in actions of global corporate citizenship.

The Forum Industry Partners involved in the Water Initiative include

$\begin{array}{lll}\text { CH2M HILL } & \text { Hindustan } & \text { Rio Tinto Group } \\ \text { Cisco Systems, Inc. } & \text { Construction } & \text { SABMiller plc } \\ \text { The Coca-Cola } & \text { Company Ltd. } & \text { Standard Chartered } \\ \text { Company } & \text { McKinsey \& } & \text { Bank } \\ \text { The Dow Chemical } & \text { Company } & \text { Syngenta AG } \\ \text { Company } & \text { Nestlé SA } & \text { Unilever } \\ \text { Halcrow Group Ltd. } & \text { PepsiCo, Inc. } & \end{array}$

\author{
With support from \\ International Finance Corporation \\ Swiss Agency for Development and Cooperation \\ United States Agency for International Development \\ Water Resources Group \\ World Wide Fund for Nature \\ World Economic Forum Global Agenda Council on Water Security

\section{And project advisory support from \\ McKinsey \& Company}

\title{
Disclaimer
}

The views expressed herein represent a collation of various viewpoints from participants in the World Economic Forum Water Initiative, the World Economic Forum Global Agenda Council on Water Security and viewpoints from other invited contributors. The text and the individual contributions do not necessarily reflect the views of every individual participant nor do they necessarily reflect the individual institutional viewpoints of any of the participating companies, institutions or organizations, or the World Economic Forum. 



\section{Water Security}

The Water-Food-Energy-Climate Nexus

The World Economic Forum Water Initiative

Washington | Covelo | London 

Copyright (C) 2011 World Economic Forum

All rights reserved under International and Pan-American Copyright Conventions. No part of this book may be reproduced in any form or by any means without permission in writing from the publisher: Island Press, 1718 Connecticut Ave., NW, Suite 300, Washington, DC 20009.

ISLAND PRESS is a trademark of The Center for Resource Economics.

Library of Congress Cataloging-in-Publication Data

Water security : the water-food-energy-climate nexus : the World Economic Forum water initiative / [edited by] Dominic Waughray.

p. $\mathrm{cm}$.

Includes bibliographical references and index.

ISBN-13: 978-1-59726-735-9 (cloth : alk. paper)

ISBN-10: 1-59726-735-X (cloth : alk. paper)

ISBN-13: 978-1-59726-736-6 (pbk. : alk. paper)

ISBN-10: 1-59726-736-8 (pbk. : alk. paper)

1. Water supply-Management. 2. Water resources development-International cooperation. 3. Water supply_Risk assessment. 4. World Economic Forum.

I. Waughray, Dominic.

HD1691.W365 2011

$333.91-\mathrm{dc} 22$

2010043396

Printed on recycled, acid-free paper

Manufactured in the United States of America

$\begin{array}{llllllllll}10 & 9 & 8 & 7 & 6 & 5 & 4 & 3 & 2 & 1\end{array}$ 



\section{Contents}

List of Illustrations xiii

Preface, Richard Samans, Managing Director, World Economic Forum $x v$

Reproduction of Opening Remarks by the United Nations Secretary General Ban

Ki-moon to the Session of the World Economic Forum Water Initiative at the

Forum's Annual Meeting in Davos, January 29, 2009 xvii

Foreword, Margaret Catley-Carlson, Patron, Global Water Partnership, Canada;

Vice-Chair, World Economic Forum Global Agenda Council on Water

Security xix

\section{INTRODUCTION}

The Water-Food-Energy-Climate Nexus: A Facts and Figures

Overview 1

Background 17

Chapter 1: Agriculture 17

Trends 20

Forecast 23

Implications 25

The Way Forward 26

Perspectives 29

Responding to the Increase in Land and Water Demand to Guarantee Future

Food Security, Pasquale Steduto, Chief, Water Development and Management

Unit, Food and Agriculture Organization, United Nations, Rome 30

Water Scarcity: Agriculture Provides Solutions, Juan Gonzalez-Valero, Head of

Public Policy and Partnerships, Syngenta AG, Switzerland; and Peleg Chevion,

Head of Business Development Water, Syngenta AG, Switzerland 33

Improving, Water, Food, and Climate Security: A Novel Approach to Direct

Seeding of Rice, Daniel Bena, Director of Sustainable Development, PepsiCo,

Inc., United States 35

Farmers Facing the Water Challenge, Ajay Vashee, International Federation

of Agricultural Producers 36

Water Challenges in the Arabian Gulf, Sir Mohammad Jaafar, Chairman and

Managing Director, Kuwaiti Danish Dairy Company, Kuwait 39

The High Cost of Priceless Water and Oman's Ancient Alternative, Peter

Brabeck-Letmathe, Chairman, Nestlé SA, Switzerland 41 
Background 44

\section{Chapter 2: Energy 44}

Trends 45

Forecast 53

Implications 55

The Way Forward 57

Perspectives 58

Water and Energy: New Thinking, Peter Gleick, President and Cofounder, Pacific Institute, United States 59

Burning Up Food as Fuel: The Role of Water, Peter Brabeck-Letmathe, Chairman, Nestlé SA, Switzerland 61

Choke Point: The Collision Between Water and Energy, J. Carl Ganter, Managing Director, Circle of Blue, United States 62

Solutions from the Sea, The Dow Chemical Company, United States 63

\section{Chapter 3: Trade 68}

Background 68

Trends 72

Forecast 74

Implications 75

The Way Forward 76

Perspectives 77

The Water-Trade Nexus, James Bacchus, Chair, Global Trade and Investment Practice, Greenberg Traurig LLP; former member of United States House of Representatives and former Chairman of the Appellate Body of the World Trade Organization 78

The Risks and Rewards of Water in Trade, Stuart Orr, Freshwater Manager, World

Wide Fund for Nature International, Gland, Switzerland; and Guy Pegram,

World Wide Fund for Nature Adviser, South Africa 80

Interlocking Crises of Water Scarcity: How Trade Can Make a Difference, Herbert Oberbänsli, Head, Economics and International Relations, Nestlé SA, Switzerland 82

Soft Approaches to Sustainable Intensification for Water Security, Tony Allan, Professor and Head, King's College London Water Research Group, United Kingdom 84

Background 88

Trends 89

Forecast 92 
Implications 96

The Way Forward 97

Perspectives 99

Trans-boundary Waters and Geopolitics by 2025, Claudia Sadoff, Lead Economist and Team Leader, South Asia Water Initiative, World Bank, Nepal 100

Hydro-solidarity as a National Security Foundation, Patricia Wouters, Director, UNESCO Centre for Water Law, Policy, and Science, University of Dundee, Scotland 102

Water in the Arabian Gulf: How to Tell the Story?, Francis Matthew, Editor at Large, Gulf News, Dubai, United Arab Emirates 104

Land: A Question of Increasing Strategic Importance in Search of BetterInformed Answers, Ralph Ashton, Convenor and Chair, Terrestrial Carbon Group, United Kingdom 105

The Water-National Security Nexus: The Case of Pakistan, John Briscoe, Gordon McKay Professor of the Practice of Environmental Engineering, Harvard University Schools of: Engineering and Applied Sciences; Public Health; and Kennedy School of Governance, United States 107

Background 111

Chapter 5: Cities 111

Trends 114

Forecast 115

Implications 116

The Way Forward 117

Perspectives 118

A Socioeconomic Breakdown, Arjun Thapan, Special Senior Adviser in Infrastructure and Water, Asian Development Bank, Manila, Philippines 119

Fatal Flooding in Modern Cities, Richard Harpin, Senior Vice-President and Head of Water Scarcity, Halcrow Group Ltd., United Kingdom 121

Creating a Wastewater Revolution in Asian Cities: The Concept of Cascading Use, Margaret Catley-Carlson, Patron, Global Water Partnership; Member, United Nations Secretary-General's Advisory Board on Water and Sanitation 123

Social Enterprise Solution for Water and Sanitation Facilities in Kenya's Slums, David Kuria, CEO and Founder, Ecotact, Kenya 124

Urban Water Supply Security and Desalination, Craig Fenton, Partner and Head of Water Sector Advisory Practice, PricewaterhouseCoopers LLP, Australia 125

Background 131

Chapter 6: People 131

Trends 132 
Forecast 134

Implications 135

The Way Forward 137

Perspectives 138

The Water Crisis Is Now, Barbara Frost, Chief Executive, WaterAid 139

Water for People: The Capacity Constraint of Governments Hinders Action, Ajit Gulabchand, Chairman and Managing Director, Hindustan Construction Company Ltd. 141

Free Access to the Water Nexus, Thabo Makgoba, Anglican Archbishop of Southern Africa 142

SaniShop: Transforming the Sanitation Crisis into a Massive Business Opportunity for All, Jack Sim, Founder and Director, World Toilet Organization, Singapore 143

Background 148

Chapter 7: Business 148

Trends 149

Forecast 155

Implications 156

The Way Forward 157

Perspectives 158

Global Water Tool, World Business Council for Sustainable Development, Geneva Switzerland 158

Water in the Value Chain, Graham Mackay, Chief Executive, SABMiller plc, United Kingdom 159

Water Resource Management and Sustainability, Jeff Seabright, Vice-President,

Environment and Water Resources, The Coca-Cola Company, United

States 161

Appendix: A Snapshot of Business Water Leadership 164

\section{Chapter 8: Finance 172}

Background 172

Trends 173

Forecast 179

Implications 180

The Way Forward 181

Perspectives 182

Financing Water, Usha Rao-Monari, Global Head of Water, Global Infrastructure and Natural Resources Department, International Finance Corporation, United States 183 
Meeting the Water Challenge, Alex Barrett, Global Head of Client Research, Standard Chartered Bank, United Kingdom 186

Water, Agriculture, and the Pricing of Sustenance, Stuart Orr, Freshwater Manager, World Wide Fund for Nature International, Gland, Switzerland; and Guy Pegram, World Wide Fund for Nature Adviser, South Africa 186 Property Rights to Water for All, David Zetland, Professor, University of California, Berkeley, United States 187

An Example of Local-Level Water Market Innovation in Sonoma, California, James G. Workman, Author and Cofounder, SmartMarkets, San Francisco, California, United States 189

\section{Chapter 9: Climate 193}

Background 193

Trends 195

Forecast and Implications 196

The Way Forward 197

Perspectives 198

Glaciers, Water Security, and Asia's Rivers, Orville Schell, [Greater China] Director, Center on US-China Relations The Asia Society, New York; Member, Global Agenda Council on Climate Change 198

Combining the What and How of Building Climate Resilience: Water Ecosystems and Infrastructure, Mark Smith, Head, International Union for Conservation of Nature Water Programme, Switzerland 201

Background 205

\section{Chapter 10: New Economic Frameworks for Decision-Making 204}

Step 1: Identifying the Demand and Supply Gap through 2030205

Step 2: How Can the Gaps between Supply and Demand Be Closed? 206

Step 3: What Technical Options for Supply and Water Productivity Exist to Close the "Water Gap"? 207

The Way Forward: A Fact-Based Analysis as a Platform for Action 211

Perspectives 213

The Work of the Water Resources Group, Herbert Oberhänsli, Head, Economics and International Relations, Nestlé SA, Switzerland 214 Water Portfolio Management, Lee A. McIntire, Chairman and CEO, CH2M HILL; and Robert Bailey, President of the Water Group, CH2M HILL 214

A "Cloud-to-Coast" Decision Framework, Michael Norton, Managing Director, Water and Power Division, Halcrow Group Ltd.; and Roger Falconer, Halcrow Professor of Water Management, Cardiff University 216 
An Integrated Sustainability Index for Effective Water Policy, Rabi H. Mohtar, Director, Global Engineering Program; Professor, Agricultural and Biological Engineering Department, Purdue University; Member, Global Agenda Council on Water Security 217

Water Skin: A Global Multi-scale River Basin Decision-Support Framework for Collaborative Water Resource and Risk Management from the Planetary Skin Institute, Juan Carlos Castilla-Rubio, President, Planetary Skin Institute; Managing Director, Cisco Systems, Inc., Sustainability and Resources Innovation Group 219

Chapter 11: Innovative Water Partnerships 225

Background 225

The Regional Platforms and Networks 226

An Evolving Process 230

The Way Forward 232

Conclusion 234

A Viewpoint from Jordan, Ministry of Planning and Internatioinal Cooperation of Jordan 237

So, How Will This Initiative Work? 239

Acknowledgments 243 


\section{Illustrations}

\section{Figures}

1.1. Commodity price evolution since June $2010 \quad 23$

1.2. Commodity price evolution since January 200624

1.3. World population, 1965-2050 31

2.1. Gas and liquid fuels value chain: Water consumption 46

2.2. Electricity industry value chain: Water consumption 50

2.3. Domestic water industry value chain: Energy consumption 53

4.1. International river basins 101

5.1. Cost reductions in large-scale desalination 127

5.2. Impact of scale on "effective" desalination costs 128

7.1. Signatories of the CEO Water Mandate, 2010150

10.1. Aggregated global gap between existing accessible, reliable, sustainable supply and 2030 water withdrawals, assuming no efficiency gains 206

10.2. Business-as-usual approaches will not meet demand for raw water 207

10.3. Representative demand- and supply-side measures 208

10.4. India: Cost of additional water availability in 2030209

10.5. Cloud-to-Coast framework 218

10.6. Energy-food-natural resources continuum: System challenge 219

\section{Tables}

2.1. Water consumption in thermoelectric power plants per unit of net power produced closed-loop cooling 51

5.1. World's largest cities facing water shortages in the past three years 114 



\section{Preface}

At the World Economic Forum Annual Meeting in Davos-Klosters in 2008, business leaders set out a Call to Action on Water; their goal was to raise awareness - to develop a better understanding of how water is linked to economic growth across a nexus of issues; and to make clear the water security challenge we face to 2030 if a business as usual approach to water management is maintained.

At the same meeting, Ban Ki-moon, UN Secretary-General, sent business a challenge: to use their call to action to help engage governments in the water discussion.

As a result, the last three years have seen an unprecedented level of discussion and analysis on water throughout the World Economic Forum's meetings and elsewhere. These discussions have been underpinned by a multicompany Water Initiative and informed by our Global Agenda Council on Water Security. This publication captures where the debate is now. It is a significant achievement. It sets out the challenge we face if nothing is done to improve water management in the next two decades. It also points to the future, introducing an important institutional initiative on water the World Economic Forum is now engaging in, to move from insight to action with the Water Resources Group.

The data and text contained in this publication are the products of a unique and unprecedented international, public-private-expert alliance to address the water challenge. It represents the multistakeholder ethos of the World Economic Forum: to bring together expertise and insight from all aspects of the economy to further the global, regional, and industry agenda on key issues, in this case water.

A broad network of World Economic Forum constituents has contributed to the ongoing success of this project. In particular, we express sincere appreciation for the foresight shown by the Industry Partners of the Water Initiative Project Board to conceive and develop this publication, and also to members of the Global Agenda Council on Water Security, past and present, for their continuous input to the overall water initiative and this book in particular.

A few special acknowledgments are due. For his vision and determination to grow the Forum's water security agenda, we are indebted to the leadership shown by Peter Brabeck-Letmathe, Chairman of Nestlé SA and Foundation 
Board Member of the World Economic Forum. Within the Forum's International Business Council, we are particularly grateful to Indra Nooyi, Chairman and CEO of PepsiCo, Inc., and Muhtar Kent, Chairman and CEO of The Coca-Cola Company, for their extraordinary partnership and commitment to the Forum's work on water. Among our governmental partners we acknowledge with gratitude the long-term support for the Forum's work on water from the Swiss Agency for Development and Cooperation led by Director General Martin Dahinden and his water team at SDC; and our important partnership with the International Finance Corporation, led by Lars Thunell, CEO and his water team at the IFC. Our gratitude and thanks are also given to Margaret Catley-Carlson, Patron of the Global Water Partnership and Chair of the World Economic Forum Water Security Global Agenda Council, 2007-2010. Her contribution to help develop the water agenda through our various convenings and meetings over the past four years has been immeasurable.

This publication also represents the collective input of more than 350 individuals who have engaged in water initiative-related discussions at our various summits and meetings in Africa, China, Europe, India, and the Middle East during 2008-10, as well as in Davos at our Annual Meetings and Dubai at our Annual Meeting of the Global Agenda.

Our thanks to you all.

Finally, for further information, please contact water@weforum.org, or visit www.weforum.org/water.

—Richard Samans, Managing Director, World Economic Forum —Dominic Waughray, Senior Director, World Economic Forum 


\section{Reproduction of Opening Remarks by the United Nations Sec- retary General Ban Ki-Moon to the Session of the World Eco- nomic Forum Water Initiative at the Forum's Annual Meeting in Davos, January 292009}

Good morning, ladies and gentlemen.

It is a pleasure to see you and pick up the conversation we began here in Davos one year ago.

Lately, I have taken to saying that the past year was one of multiple crises. We have the economic crisis, the food crisis, the energy crisis. To these we can add climate change. All of these crises are still very much with us. They illustrate our world's vulnerability to the shock of diminishing resources. And as you all know only too well, water is very much near the top of the list. Your work is therefore essential and I commend you for it. Over the past year you have come togetheracademics, business people, government leaders - and put this issue on the global agenda. People are beginning to realize how connected it is to so many challenges-development, peace and security, economic growth. The global public has become increasingly aware how climate change and water scarcity threaten the populations of heavily settled parts of the world. They understand how it breeds conflict. They know how man-made climate change and growing consumption of water are putting unprecedented stress on this dwindling resource. The good news is that we also know how technology can play an important role in mitigating water stress. Many technologies_-new and ancient-can improve water, for example, supplying more water from sea-water, harvesting rainfall or deploying new and simple methods of irrigation that save water. Farmers can diversify crops and plant drought-resistant seeds. All this we know. The problem is that we have no coordinated global management authority in the UN system or the world at large. There is no overall responsibility, accountability or vision for how to address the related problems of climate change, agricultural stress and water technology. This is where you come in. Some of you are members of the Global Compact's CEO Water Mandate, which I introduced here last year and has already made substantial progress. I hope many more of you will join. Your work to create a water security Global Agenda Council is essential. So is your effort to develop the economic and geopolitical forecast you are discussing today. For the first time, you are bringing together all the different perspectives and expertise required to define the full dimension of the problem and propose solutions. In doing so, you are creating the framework of a future partnership - bringing together businesses, governments, universities and NGOs. The problem is broad and systemic. Our work to deal with it must be so as well.

I look forward to seeing your work completed. I will help in any way I can. 



\section{Foreword}

In 1911, John Muir observed how "when we try to pick out anything by itself in nature, we find it hitched to everything else in the universe." A century later, a gathering of the World Economic Forum discovered the same phenomenon. Four hundred top decision-makers listed the myriad looming threats to global stability, including famine, terrorism, inequality, disease, poverty, and climate change. Yet when we tried to address each diverse force, we found them all attached to one universal security risk: fresh water.

To some degree, water stress is as old as time. But in past societies, scarcity found relief through commerce, as parched regions could import from greener pastures. That pressure valve no longer exists on our hot, hungry, crowded, and fast-evaporating planet. A recent McKinsey \& Company study found that within two decades, the collective demand of humans for water will exceed foreseen supply by about $40 \%$. That shortage escalates food prices, disrupts energy, constricts trade, creates refugees, and undermines authority. Thirst is now global.

Our collaboration illustrates where and why water is, quite literally, "hitched to everything else in the universe." Water infuses not only our ground beef patty, lettuce, cheese, pickles, onions, ketchup, and sesame seed bun, but also the bag and packaging in which that hamburger is provided, the building in which it was grilled, the energy to cook it, and the financial system that lent the franchise capital. River currents turn turbines or grow fuel or cool plants that generate its electrical currents. On fresh water dangles the life or death of five thousand children each day, the clothing they wear, and whether their weak governing state will grow stable or start to unravel. Water is the single constraint on the expansion of every city, and bankers and corporate executives have cited it as the only natural limit to economic growth. What is striking is that the water nexus has remained on the periphery of priorities for so many for so long. This work seeks to transform our often-willful ignorance into intense interest and informed, pragmatic action.

This volume binds decades of collaborative work by seasoned veterans in the contentious yet fascinating struggle to quench human thirst. Yet this landmark book did not emerge overnight, out of nowhere. It builds on years of debate in dozens of meetings, initially gaining traction in an earlier report prepared for the Davos-Klosters Annual Meeting in 2009 titled The Bubble Is Close to Bursting. Water Security, however, pushes much further. It presents not only an urgent warning and unique forecast, but also offers positive recommendations; diverse perspectives, profound insights, and pragmatic case 
studies by public and private authorities confirm the vital role water can and must play over the next two decades to secure the world's economy.

Water is an astonishingly complex and subtle force in that economy, shaping decisions in ways we only now begin to appreciate. But this much is already clear: if "business-as-usual" water management practices continue for another two decades, large parts of the world will face a serious and structural threat to economic growth, human well-being, and national security. Some will feel the heat sooner than others. Indeed, today we see troubling signs of flash points to come. Against various trend lines in agriculture, energy, climate change, urban growth, infrastructure, population, and environmental stress, this book will argue why we simply cannot manage water in the future as we have done in the past.

In 2009, the Forum's Industry Partners and Global Agenda Council on Water Security united to augment, revise, and strengthen the chapters that form this book's thematic backbone. That same year, the Forum persuaded an extraordinary group of CEOs, water experts, NGO heads, scientists, and international officials to provide insights on the various challenges to our common water future and how we must navigate them.

The next phase of the World Economic Forum's Water Initiative will build on the platform, analysis, and decision-making framework inscribed in this book. Yet the work in your hands is neither definitive nor final. Indeed, Water Security is by no means is the ultimate word. It merely introduces a fresh tributary into a broad-based and collaborative current, seeking an efficient, productive, and equitable journey towards a natural cycle of rebirth and renewal.

-Margaret Catley-Carlson, Patron, Global Water Partnership, Canada; Vice-Chair, World Economic Forum Global Agenda Council on Water Security 